\title{
Transgenic Expression of dsRNA Targeting the Pentalonia nigronervosa acetylcholinesterase Gene in Banana and Plantain Reduces Aphid Populations
}

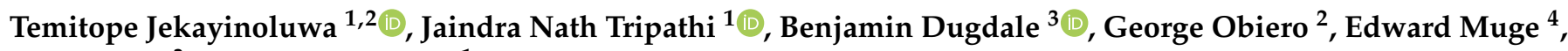 \\ James Dale ${ }^{3}$ and Leena Tripathi ${ }^{1, *}$ \\ 1 International Institute of Tropical Agriculture, Biosciences, P.O. Box 30709, Nairobi 00100, Kenya; \\ temitopejekayinoluwa@gmail.com (T.J.); J.Tripathi@cgiar.org (J.N.T.) \\ 2 Center for Biotechnology and Bioinformatics, University of Nairobi, 30197, Nairobi 00100, Kenya; \\ george.obiero@uonbi.ac.ke \\ 3 Center for Agriculture and the Bioeconomy, Queensland University of Technology, \\ Brisbane, QLD 4000, Australia; b.dugdale@qut.edu.au (B.D.); j.dale@qut.edu.au (J.D.) \\ 4 Department of Biochemistry, University of Nairobi, 30197, Nairobi 00100, Kenya; mugeek@uonbi.ac.ke \\ * Correspondence: L.Tripathi@cgiar.org
}

Citation: Jekayinoluwa, T.; Tripathi, J.N.; Dugdale, B.; Obiero, G.; Muge, E.; Dale, J.; Tripathi, L. Transgenic Expression of dsRNA Targeting the Pentalonia nigronervosa acetylcholinesterase Gene in Banana and Plantain Reduces Aphid Populations. Plants 2021, 10, 613. https://doi.org/10.3390/ plants10040613

Academic Editor:

Daniel-Valentin Savatin

Received: 9 January 2021

Accepted: 22 March 2021

Published: 24 March 2021

Publisher's Note: MDPI stays neutral with regard to jurisdictional claims in published maps and institutional affiliations.

Copyright: (c) 2021 by the authors. Licensee MDPI, Basel, Switzerland. This article is an open access article distributed under the terms and conditions of the Creative Commons Attribution (CC BY) license (https:/ / creativecommons.org/licenses/by/ $4.0 /)$.
Abstract: The banana aphid, Pentalonia nigronervosa, is the sole insect vector of banana bunchy top virus (BBTV), the causal agent of banana bunchy top disease. The aphid acquires and transmits BBTV while feeding on infected banana plants. RNA interference (RNAi) enables the generation of pest and disease-resistant crops; however, its effectiveness relies on the identification of pivotal gene sequences to target and silence. Acetylcholinesterase (AChE) is an essential enzyme responsible for the hydrolytic metabolism of the neurotransmitter acetylcholine in animals. In this study, the AChE gene of the banana aphid was targeted for silencing by RNAi through transgenic expression of $A C h E$ dsRNA in banana and plantain plants. The efficacy of dsRNA was first assessed using an artificial feeding assay. In vitro aphid feeding on a diet containing $7.5 \%$ sucrose, and sulfate complexes of trace metals supported aphid growth and reproduction. When $A C h E$ dsRNA was included in the diet, a dose of $500 \mathrm{ng} / \mu \mathrm{L}$ was lethal to the aphids. Transgenic banana cv. Cavendish Williams and plantain cvs. Gonja Manjaya and Orishele expressing AChE dsRNA were regenerated and assessed for transgene integration and copy number. When aphids were maintained on elite transgenic events, there was a $67.8 \%, 46.7 \%$, and $75.6 \%$ reduction in aphid populations growing on Cavendish Williams, Gonja Manjaya, and Orishele cultivars, respectively, compared to those raised on nontransgenic control plants. These results suggest that RNAi targeting an essential aphid gene could be a useful means of reducing both aphid infestation and potentially the spread of the disease they transmit.

Keywords: RNA interference; acetylcholinesterase; banana; plantain; banana aphid; sugars; artificial diet

\section{Introduction}

Banana bunchy top disease (BBTD) is one of the most economically important diseases affecting banana and plantain (Musa spp.) production [1,2]. BBTD is caused by the banana bunchy top virus (BBTV) and is transmitted within short distances by banana aphids (Pentalonia nigronervosa Coquerel, superfamily Aphididae, order Hemiptera) or long distances through infected planting materials [3]. In severe cases, the disease can cause up to $100 \%$ yield loss [4]. Excessive use of insecticides to control the spread of BBTD by aphids is not ideal due to environmental risks, the potential for adverse effects to off-target organisms and long-term acquired insecticide resistance [5]. Breeding for natural resistance to the banana aphid would be one approach of curtailing the disease. However, there are no banana/plantain germplasms with resistance to aphids, and moreover, breeding of banana is both time-consuming and challenging. Molecular breeding offers an alternative approach 
for crop improvement. The availability of robust and reproducible transformation systems for banana have made it possible to genetically modify this crop for enhanced agronomic traits [6-9]. The development of aphid-resistant banana and plantain cultivars through genetic modification could provide a durable strategy towards controlling BBTD.

RNA interference (RNAi) is a post-transcriptional gene silencing mechanism that has proven to be effective against some insect pests, including the coleopteran, lepidopteran, and hemipteran orders [10-15]. These studies showed that the insecticidal effectiveness of RNAi is strongly dependent on the selected target gene and other factors such as dsRNA fragment length and the relative susceptibilities of different insect developmental stages. For example, of the nine genes targeted against Myzus persicae (green peach aphid), dsRNAs specific for the $V$-ATPaseE and TBCD genes were the most effective, while expression of an artificial micro (ami) RNA targeting the $A C h E 2$ gene provided greater aphid resistance compared to hairpin (hp) RNA-expressing plants [16]. Likewise, targeting the E-subunit of the $V$-ATPase gene resulted in suppression of a broader range of insects, including Tribolium castaneum, Manduca sexta, Acyrthosiphon pisum, and Drosophila melanogaster [17]. In addition, planthoppers (Nilaparvata lugens) fed on transgenic rice plants expressing dsRNA against the NlHT1, Nlcar and Nltry genes showed reduced target transcript levels in their midgut, but no lethality was observed [11].

Acetylcholinesterase (AChE) is an enzyme that catalyzes the breakdown of acetylcholine and plays a significant role in the physiology and survival of insects [16]. Anticholinesterase compounds such as organophosphate, carbamate, chlorpyrifos, and methamidophos phosphorylate [18-21] are commonly employed as insecticides to control agricultural insects and pests [18-21]. Blocking AChE function can cause mortality, malformation, and/or inhibit adequate growth.

An artificial diet is an essential step for developing a noninvasive tool for gene functionality studies and validating candidate target genes for RNAi-mediated control of aphids. To date, no artificial diet has been developed for banana aphid, so in this study we developed a well-suited synthetic diet by optimizing existing diets. The optimized diet was further used to study the effect of dsRNA-AChE ingestion on banana aphids under a controlled condition.

In this study, we report the effect of $A C h E$ dsRNA uptake on the banana aphid, Pentalonia nigronervosa. To do this, we first developed an artificial liquid feeding complex containing sucrose and increasing levels of $A C h E$ dsRNA. Aphids fed on the dsRNA-containing media were monitored over time for mortality. Transgenic banana and plantain expressing hpRNA targeting the AChE gene were then generated by Agrobacterium-mediated transformation of cell suspensions. Plants were genetically characterized, and elite events inoculated with aphids in a controlled environment chamber. Aphid populations were greatly reduced on some transgenic events compared to those on the control nontransgenic plants.

\section{Results and Discussion}

\subsection{Optimization of an In Vitro Feeding Diet for Banana Aphids}

Four diet formulas (Diets 1-4) and water as control (Diet 5), containing increasing levels of sucrose, were assessed for their capacity to support aphid growth over five and seven days (Table 1). Diets 1, 2, 3, and 4 supported aphid growth, with the highest mean aphid and nymph populations observed on Diet 2 containing sucrose at a level of $7.5 \mathrm{~g} / 100 \mathrm{~mL}$ at day 5 (mean number of aphids $=3.83 \pm 0.5$; mean number of nymphs $=8.44 \pm 1.8$ ) and day 7 (mean number of aphid $=4.0 \pm 0$; mean number of nymph $=9.8 \pm 1.2$ ). Sucrose levels between 5 and $20 \mathrm{~g} / 100 \mathrm{~mL}$ were most suitable to support the survival of banana aphids. Highest aphid mortality was observed in Diets 1-4 containing no sugar or very high sucrose $(30 \mathrm{~g} / 100 \mathrm{~mL})$ and in the control Diet 5 due to the lack of essential nutrients. The intrinsic rate of natural increase and finite rate was highest in Diet 2 at $7.5 \mathrm{~g} / 100 \mathrm{~mL}$ sucrose concentration (Figure 1). These results showed that diet composition and sucrose levels are important factors for aphid growth and that a diet with balanced carbohydrates and amino acids is likely essential for aphid survival and reproduction [22]. Furthermore, 
trace metals like iron, zinc, manganese, and copper are vital for aphid reproduction [23]. The availability of some of these minerals either in chelated (Diet 1) or sulfate (Diet 2) forms supported the development and reproduction of banana aphids. In addition, Diets 3 and 4 , which contained sulfate and chloride complexes without the inclusion of trace metals, supported the growth of banana aphids for the period tested. This could be due to the availability of magnesium as well as amino acid-containing compounds in the diet. A study on pea aphids $[24,25]$ confirmed that the use of trace elements $(\mathrm{Fe}, \mathrm{Cu}, \mathrm{Mn}$, and $\mathrm{Zn})$ in sequestrate forms, improved the viability of these aphids. In this study, sulfate complexes were used for all the trace metals in Diet 2 due to the unavailability of a sequestered form of manganese. Despite this, aphid growth and reproduction did not appear to be compromised. However, an extended period of feeding is required to further confirm this finding.

Table 1. Effect of sucrose levels and diet type on banana aphid survival.

\begin{tabular}{|c|c|c|c|c|c|}
\hline Day & Sucrose Level (g/100 mL) & Diet Type & NDA & NLA & NN \\
\hline \multirow{30}{*}{5} & \multirow{5}{*}{0} & Diet 1 & $4.0 \pm 0^{\mathrm{ns}}$ & $0 \pm 0^{\mathrm{ns}}$ & $0.08 \pm 0.3^{\mathrm{ns}}$ \\
\hline & & Diet 2 & $4.0 \pm 0^{\mathrm{ns}}$ & $0 \pm 0^{\mathrm{ns}}$ & $0.05 \pm 0.2^{\mathrm{ns}}$ \\
\hline & & Diet 3 & $4.0 \pm 0^{\mathrm{ns}}$ & $0 \pm 0^{\mathrm{ns}}$ & $0.13 \pm 0.4^{\mathrm{ns}}$ \\
\hline & & Diet 4 & $4.0 \pm 0^{\mathrm{ns}}$ & $0.08 \pm 0.3^{\mathrm{ns}}$ & $0.33 \pm 0.7^{\mathrm{ns}}$ \\
\hline & & Control & $4.0 \pm 0$ & $0 \pm 0$ & $0.08 \pm 0.3$ \\
\hline & \multirow{5}{*}{5} & Diet 1 & $2.0 \pm 1.0^{* *}$ & $1.75 \pm 1.6^{* *}$ & $3.5 \pm 1.7^{* * *}$ \\
\hline & & Diet 2 & $1.0 \pm 1.1^{* * *}$ & $3.2 \pm 1.2^{* * *}$ & $5.73 \pm 2.7^{* * *}$ \\
\hline & & Diet 3 & $1.0 \pm 1^{* * *}$ & $3.13 \pm 1.1^{* * *}$ & $3.73 \pm 1.0^{* * *}$ \\
\hline & & Diet 4 & $1.0 \pm 1^{* * *}$ & $3.25 \pm 1.1^{* * *}$ & $3.66 \pm 1.8^{* * *}$ \\
\hline & & Control & $4.0 \pm 1.0$ & $0.16 \pm 0.6$ & $0.25 \pm 0.5$ \\
\hline & \multirow{5}{*}{7.5} & Diet 1 & $1.5 \pm 1.5^{* * *}$ & $2.5 \pm 1.5^{* * *}$ & $3.08 \pm 1.8^{* *}$ \\
\hline & & Diet 2 & $0.17 \pm 0.5^{* * *}$ & $3.83 \pm 0.5^{* * *}$ & $8.44 \pm 1.8^{* * *}$ \\
\hline & & Diet 3 & $0.71 \pm 0.9^{* * *}$ & $3.28 \pm 0.9^{* * *}$ & $4.21 \pm 0.9^{* * *}$ \\
\hline & & Diet 4 & $1.25 \pm 1.4^{* * *}$ & $2.75 \pm 1.4^{* * *}$ & $3.66 \pm 1.9^{* * *}$ \\
\hline & & Control & $3.33 \pm 1.1$ & $0.66 \pm 1.1$ & $0.83 \pm 1.3$ \\
\hline & \multirow{5}{*}{15} & Diet 1 & $1.5 \pm 1.7 *$ & $2.5 \pm 1.7 *$ & $3.08 \pm 1.9^{* *}$ \\
\hline & & Diet 2 & $0.78 \pm 0.7^{* * *}$ & $3.21 \pm 0.7^{* * *}$ & $5.35 \pm 2.2^{* * *}$ \\
\hline & & Diet 3 & $1.2 \pm 1.5^{* *}$ & $2.8 \pm 1.5^{* *}$ & $3.26 \pm 1.6^{* * *}$ \\
\hline & & Diet 4 & $0.66 \pm 0.8^{* * *}$ & $3.33 \pm 0.8^{* * *}$ & $3.0 \pm 1.6^{* *}$ \\
\hline & & Control & $2.8 \pm 1.3$ & $1.16 \pm 1.3$ & $0.75 \pm 1.1$ \\
\hline & \multirow{5}{*}{20} & Diet 1 & $2.3 \pm 1.9^{\mathrm{ns}}$ & $1.67 \pm 1.9^{\mathrm{ns}}$ & $2.16 \pm 1.9^{\mathrm{ns}}$ \\
\hline & & Diet 2 & $1.4 \pm 1.2^{\mathrm{ns}}$ & $2.6 \pm 1.2^{\mathrm{ns}}$ & $3.0 \pm 1.8^{* * *}$ \\
\hline & & Diet 3 & $1.33 \pm 1.3^{\mathrm{ns}}$ & $2.66 \pm 1.3^{\mathrm{ns}}$ & $2.53 \pm 1.5^{* *}$ \\
\hline & & Diet 4 & $1.16 \pm 1.3 *$ & $2.83 \pm 1.3 *$ & $2.58 \pm 0.7^{* *}$ \\
\hline & & Control & $2.66 \pm 1.6$ & $1.33 \pm 1.6$ & $0.75 \pm 0.9$ \\
\hline & \multirow{5}{*}{30} & Diet 1 & $3.08 \pm 1.7^{\mathrm{ns}}$ & $0.83 \pm 1.6^{\mathrm{ns}}$ & $1.08 \pm 1.3^{\mathrm{ns}}$ \\
\hline & & Diet 2 & $3.13 \pm 1.12^{\mathrm{ns}}$ & $0.86 \pm 1.1^{\mathrm{ns}}$ & $0.46 \pm 0.8^{\mathrm{ns}}$ \\
\hline & & Diet 3 & $3.00 \pm 1.5^{\mathrm{ns}}$ & $0.86 \pm 1.2^{\mathrm{ns}}$ & $0.86 \pm 1.3^{\mathrm{ns}}$ \\
\hline & & Diet 4 & $3.66 \pm 0.5^{\mathrm{ns}}$ & $0.33 \pm 0.5^{\mathrm{ns}}$ & $0.42 \pm 0.7^{\mathrm{ns}}$ \\
\hline & & Control & $3.58 \pm 0.8$ & $0.42 \pm 0.8$ & $0.25 \pm 0.5$ \\
\hline
\end{tabular}


Table 1. Cont.

\begin{tabular}{|c|c|c|c|c|c|}
\hline Day & Sucrose Level $(\mathrm{g} / 100 \mathrm{~mL})$ & Diet Type & NDA & NLA & $\mathbf{N N}$ \\
\hline \multirow{30}{*}{7} & \multirow{5}{*}{0} & Diet 1 & $4.0 \pm 0^{\mathrm{ns}}$ & $0 \pm 0^{\mathrm{ns}}$ & $0 \pm 0^{\mathrm{ns}}$ \\
\hline & & Diet 2 & $4.0 \pm 0^{\mathrm{ns}}$ & $0.0 \pm 0^{\mathrm{ns}}$ & $0 \pm 0^{\mathrm{ns}}$ \\
\hline & & Diet 3 & $4.0 \pm 0^{\mathrm{ns}}$ & $0 \pm 0^{\mathrm{ns}}$ & $0.33 \pm 0.5^{\mathrm{ns}}$ \\
\hline & & Diet 4 & $3.83 \pm 0.4^{\mathrm{ns}}$ & $0.16 \pm 0.4^{\mathrm{ns}}$ & $0.66 \pm 0.8^{*}$ \\
\hline & & Control & $4.0 \pm 0$ & $0 \pm 0$ & $0 \pm 0$ \\
\hline & \multirow{5}{*}{5} & Diet 1 & $2.5 \pm 1.5^{\mathrm{ns}}$ & $1.66 \pm 1.9^{\mathrm{ns}}$ & $3.0 \pm 2.1^{\mathrm{ns}}$ \\
\hline & & Diet 2 & $1.0 \pm 1.5^{* *}$ & $3.0 \pm 1.5^{* *}$ & $6 \pm 3.7^{* * *}$ \\
\hline & & Diet 3 & $0.5 \pm 0.8^{* * *}$ & $3.5 \pm 0.8^{* * *}$ & $4.16 \pm 0.8^{* *}$ \\
\hline & & Diet 4 & $1.0 \pm 1.5^{* *}$ & $3.0 \pm 1.5^{* *}$ & $4.0 \pm 1.1^{* *}$ \\
\hline & & Control & $3.66 \pm 0.8$ & $0.33 \pm 0.8$ & $0.5 \pm 0.5$ \\
\hline & \multirow{5}{*}{7.5} & Diet 1 & $0.83 \pm 1.0^{*}$ & $3.16 \pm 1.0 * *$ & $4.5 \pm 1.2 * *$ \\
\hline & & Diet 2 & $0.0 \pm 0 * *$ & $4.0 \pm 0^{* * *}$ & $9.8 \pm 1.2^{* * *}$ \\
\hline & & Diet 3 & $1.16 \pm 1.2^{\mathrm{ns}}$ & $2.83 \pm 1.2^{\mathrm{ns}}$ & $4.33 \pm 1.0 * *$ \\
\hline & & Diet 4 & $0.66 \pm 1.6^{* *}$ & $3.33 \pm 1.6^{* *}$ & $4.83 \pm 2.0^{* * *}$ \\
\hline & & Control & $2.83 \pm 1.3$ & $1.16 \pm 1.3$ & $1.5 \pm 1.6$ \\
\hline & \multirow{5}{*}{15} & Diet 1 & $0.66 \pm 1.2^{* *}$ & $3.33 \pm 1.2^{* *}$ & $3.66 \pm 1.6^{*}$ \\
\hline & & Diet 2 & $0.4 \pm 0.5^{* *}$ & $3.6 \pm 0.5^{* *}$ & $7.2 \pm 0.8^{* * *}$ \\
\hline & & Diet 3 & $2.16 \pm 1.8^{\mathrm{ns}}$ & $1.83 \pm 1.8^{\mathrm{ns}}$ & $3.66 \pm 2.0^{*}$ \\
\hline & & Diet 4 & $0.5 \pm 0.8^{* *}$ & $3.5 \pm 0.8^{* *}$ & $3.66 \pm 1.9 *$ \\
\hline & & Control & $3.16 \pm 1.3$ & $0.8 \pm 1.3$ & $1.17 \pm 1.2$ \\
\hline & \multirow{5}{*}{20} & Diet 1 & $2.5 \pm 2.0^{\mathrm{ns}}$ & $1.5 \pm 2.0^{\mathrm{ns}}$ & $3.16 \pm 2.1^{*}$ \\
\hline & & Diet 2 & $1.16 \pm 1.2^{\mathrm{ns}}$ & $2.83 \pm 1.2^{\mathrm{ns}}$ & $4.5 \pm 2.0$ *** \\
\hline & & Diet 3 & $1.83 \pm 1.2^{\mathrm{ns}}$ & $2.16 \pm 1.2^{\mathrm{ns}}$ & $3.33 \pm 1.0 *$ \\
\hline & & Diet 4 & $1.5 \pm 1.5^{\mathrm{ns}}$ & $2.5 \pm 1.5^{\mathrm{ns}}$ & $2.66 \pm 0.8^{\mathrm{ns}}$ \\
\hline & & Control & $2.16 \pm 2.0$ & $1.83 \pm 2.0$ & $1.0 \pm 0.9$ \\
\hline & \multirow{5}{*}{30} & Diet 1 & $4.0 \pm 0^{\mathrm{ns}}$ & $0 \pm 0^{\mathrm{ns}}$ & $0.83 \pm 1.2^{\mathrm{ns}}$ \\
\hline & & Diet 2 & $3.33 \pm 0.8^{\mathrm{ns}}$ & $0.66 \pm 0.8^{\mathrm{ns}}$ & $0.33 \pm 0.8^{\mathrm{ns}}$ \\
\hline & & Diet 3 & $2.83 \pm 1.5^{\mathrm{ns}}$ & $1.16 \pm 1.5^{\mathrm{ns}}$ & $1.83 \pm 1.5^{*}$ \\
\hline & & Diet 4 & $3.83 \pm 0.4^{\mathrm{ns}}$ & $0.16 \pm 0.4^{\mathrm{ns}}$ & $0.66 \pm 0.8^{\mathrm{ns}}$ \\
\hline & & Control & $3.44 \pm 0.9$ & $0.55 \pm 0.9$ & $0.33 \pm 0.5$ \\
\hline \multicolumn{6}{|c|}{ Main effect $p$-value } \\
\hline \multicolumn{3}{|c|}{ SL } & $* * *$ & $* * *$ & $* * *$ \\
\hline \multicolumn{3}{|c|}{ DT } & $* * *$ & $* * *$ & $* * *$ \\
\hline \multicolumn{2}{|r|}{ Day } & & ns & ns & $* * *$ \\
\hline & Day*SL*DT & & $* * *$ & $* * *$ & $* * *$ \\
\hline
\end{tabular}

Note: NDA: number of dead aphids, NLA: number of live aphids, NN: number of nymphs, SL: sucrose level, DT: diet type, Diet 5: control diet. Starting point is the day of inoculation of aphid on diet $=0$. The data were analyzed using the two-way ANOVA and presented as mean and standard deviation of live aphid, dead aphid, and nymph. The multiple comparison by Dunnett's test was performed and indicated as ns, nonsignificant $(p>0.05) ;{ }^{*}$ significant $(p \leq 0.05) ;{ }^{* *}$ very significant $(p \leq 0.01) ;{ }^{* * *}$ highly significant $(p \leq 0.001)$. Two independent experiments using three replicates with four aphids each per diet $(n=24)$ were performed. 

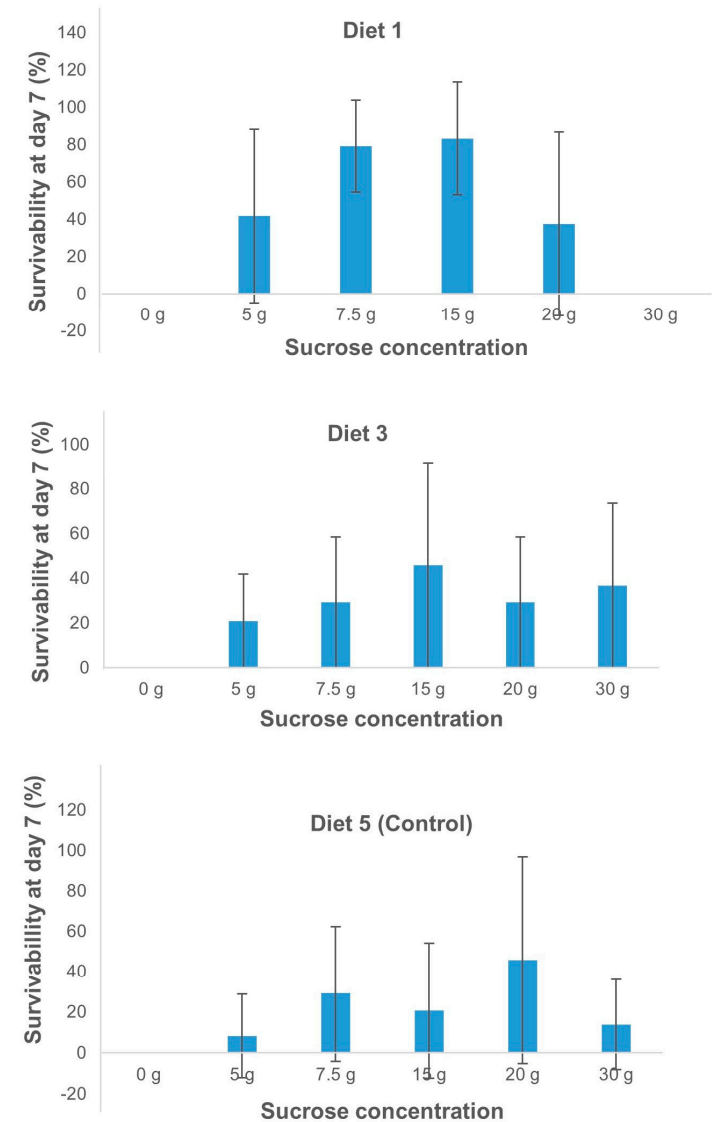
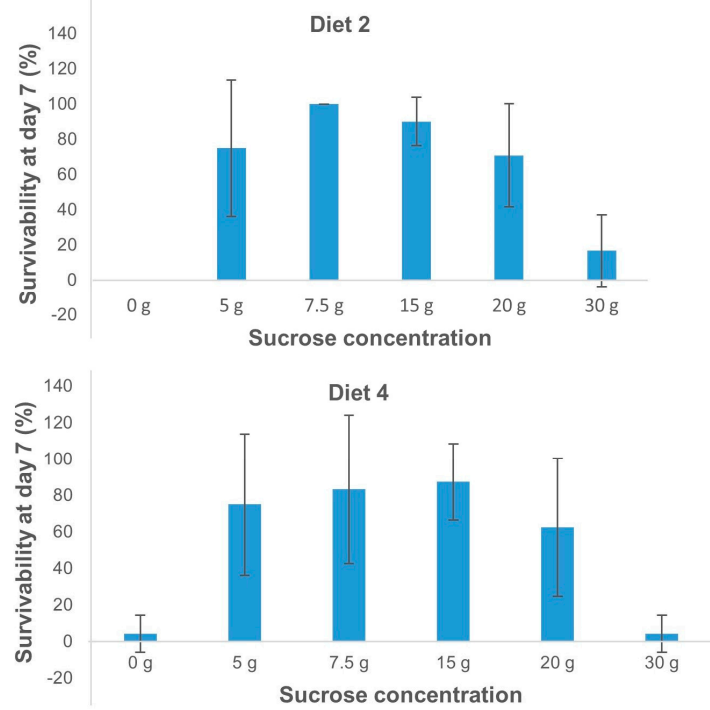

Figure 1. Survivability of banana aphids at day 7 post-feeding on various diets supplemented with different concentrations of sucrose. Data are presented as mean percentage survivability (\%) and error lines indicate the standard deviation.

\subsection{Dose Effects of dsRNA-AChE on Survival of Banana Aphids}

Synthetic Diet 2 (containing $7.5 \mathrm{~g} / 100 \mathrm{~mL}$ sucrose), identified as a suitable diet composition for banana aphid feeding and growth, was supplemented with dsRNA- $A C h E$ at increasing concentrations of $0,100,200,300$, and $500 \mathrm{ng} / \mu \mathrm{L}$ to determine its effects on aphid survival. By monitoring aphid numbers over 2, 3, and 7 days of feeding, increasing concentrations of dsRNA- $A C h E$ were shown to significantly impact aphid survival, with a dose of $500 \mathrm{ng} / \mu \mathrm{L}$ of dsRNA having the highest lethality (Table 2, Figure 2).

$A C h E$ is an essential enzyme in the aphid life cycle [16] and is known to activate the breakdown of acetylcholine (ACh) through hydrolysis, thereby preventing possible adverse effects associated with overaccumulation of an impulse generated by this neurotransmitter [26]. Choline and acetate ions are the byproducts of the reaction. Choline reinitiates the production of $A C h E$, while acetate ion plays a vital role in the synthesis of fatty acids and carbohydrates when it combines with coenzyme A [27]. AChE, therefore, represents a key enzyme target to control crop pests like aphids [28]. 
Table 2. Effect of varying concentrations of dsRNA-AChE on banana aphid mortality, survival, and reproduction.

\begin{tabular}{|c|c|c|c|c|}
\hline Treatment (ng) & Day & NDA & NLA & $\mathbf{N N}$ \\
\hline \multirow{3}{*}{100} & 2 & $0 \pm 0^{\mathrm{ns}}$ & $4 \pm 0^{\mathrm{ns}}$ & $2.5 \pm 0.7^{\mathrm{ns}}$ \\
\hline & 3 & $0 \pm 0^{\mathrm{ns}}$ & $4 \pm 0^{\mathrm{ns}}$ & $3.5 \pm 0.7^{\mathrm{ns}}$ \\
\hline & 7 & $0.5 \pm 0.7^{\mathrm{ns}}$ & $3.5 \pm 0.7^{* * *}$ & $6 \pm 1.4^{\mathrm{ns}}$ \\
\hline \multirow{3}{*}{200} & 2 & $0.5 \pm 0.7^{\mathrm{ns}}$ & $3.5 \pm 0.7^{\mathrm{ns}}$ & $2.5 \pm 2.1^{\mathrm{ns}}$ \\
\hline & 3 & $0.6 \pm 0.9^{\mathrm{ns}}$ & $3.6 \pm 1.1^{\mathrm{ns}}$ & $3.4 \pm 1.5^{\mathrm{ns}}$ \\
\hline & 7 & $1.0 \pm 1.4^{\mathrm{ns}}$ & $3.0 \pm 1.4^{* * *}$ & $7.0 \pm 4.2^{\mathrm{ns}}$ \\
\hline \multirow{3}{*}{300} & 2 & $0 \pm 0^{\mathrm{ns}}$ & $4.0 \pm 0^{\mathrm{ns}}$ & $3.0 \pm 1.4^{\mathrm{ns}}$ \\
\hline & 3 & $1.0 \pm 0^{\mathrm{ns}}$ & $3.0 \pm 0^{\mathrm{ns}}$ & $2.5 \pm 0.7^{\mathrm{ns}}$ \\
\hline & 7 & $1.0 \pm 1.4^{\mathrm{ns}}$ & $3.0 \pm 1.4^{* * *}$ & $4.5 \pm 2.1^{* * *}$ \\
\hline \multirow{3}{*}{500} & 2 & $1.0 \pm 1.4^{\mathrm{ns}}$ & $3.0 \pm 1.4^{\mathrm{ns}}$ & $1.5 \pm 0.7^{\mathrm{ns}}$ \\
\hline & 3 & $2.83 \pm 1.8^{* * *}$ & $1.16 \pm 1.8^{* * *}$ & $0.66 \pm 1.2^{* * *}$ \\
\hline & 7 & $3.5 \pm 0.7^{* *}$ & $0.5 \pm 0.7^{* *}$ & $3.5 \pm 2.1 *$ \\
\hline \multirow{3}{*}{ Control } & 2 & $0 \pm 0$ & $4.0 \pm 0$ & $4.0 \pm 0.7$ \\
\hline & 3 & $0.11 \pm 0.3$ & $3.88 \pm 0.3$ & $5.33 \pm 2.5$ \\
\hline & 7 & $0.43 \pm 0.5$ & $3.57 \pm 0.5$ & $8.86 \pm 1.9$ \\
\hline \multicolumn{5}{|l|}{$\begin{array}{c}\text { Main effect } \\
p \text {-value }\end{array}$} \\
\hline Treatment & & $* * *$ & $* * *$ & $* * *$ \\
\hline Day & & * & * & $* * *$ \\
\hline Treatment ${ }^{*}$ Day & & ns & ns & ns \\
\hline
\end{tabular}

Note: NDA: number of dead aphids, NLA: number of live aphids, NN: number of nymphs. Data were analyzed by two-way ANOVA to obtain the main effect and Dunnett's test for comparison with control. Data are presented as mean and standard deviation of live aphid, dead aphid, and nymph; ns, nonsignificant $(p>0.05)$; ${ }^{*}$ significant $(p \leq 0.05) ;{ }^{* *}$ very significant $(p \leq 0.01) ;{ }^{* * *}$ highly significant $(p \leq 0.001)$. Two independent experiments using three replicates with four aphids each per $\operatorname{diet}(n=24)$ were performed.

The optimum lethal dose of $500 \mathrm{ng} / \mu \mathrm{L}$ dsRNA-AChE for Pentalonia nigronervosa in this study is about three-fold higher than that for the Asian citrus psyllid (Diaphorina citri) (125 ng/ $\mu \mathrm{L}$ dsRNA-AChE) [28], but two-fold lower than that for the BC-Actin gene $(1000 \mathrm{ng} / \mu \mathrm{L})$ of Bactericera cockerelli that was required to reduce gene expression levels [29]. Other studies showed that an injection delivery procedure of $5 \mu \mathrm{g} d s R \mathrm{NA}-A C h E$ in Tuta absoluta caused 63\% mortality [30].

\subsection{Generation and Molecular Characterization of Transgenic Events}

In total, 80 putative transgenic plants were generated on selective regeneration media supplemented with kanamycin (100 mg/L) (Figure 3) following Agrobacterium-mediated transformation of embryogenic cell suspensions of Cavendish Williams, Orishele, and Gonja Manjaya. PCR using primers designed to amplify a $466 \mathrm{bp}$ fragment of the $A C h E$ hairpin (Figure 4) showed the presence of the transgene in 79 events out of 80 transgenic events tested. The integration and copy number of the transgene was determined by Southern blot analysis using a digoxigenin (DIG)-labeled probe specific for the $A C h E$ gene fragment. Based on unique hybridization signals, all plants were likely independent transgenic events. Of the selected PCR positive events analyzed by Southern hybridization, total of 4,8, and 11 events of Cavendish Williams, Orishele, and Gonja Manjaya showed a single copy number of transgene, respectively (Figure 5). Further, RT-PCR analysis was performed to confirm the expression of the $A C h E$ transgene in a subset of transgenic plants. Although not a quantitative assay, the intensity of RT-PCR amplicons following agarose gel electrophoresis suggested that these events varied in dsRNA- $A C h E$ expression levels 
with only one event of Gonja Manjaya and three events of Orishele having undetectable levels (Figure 6).

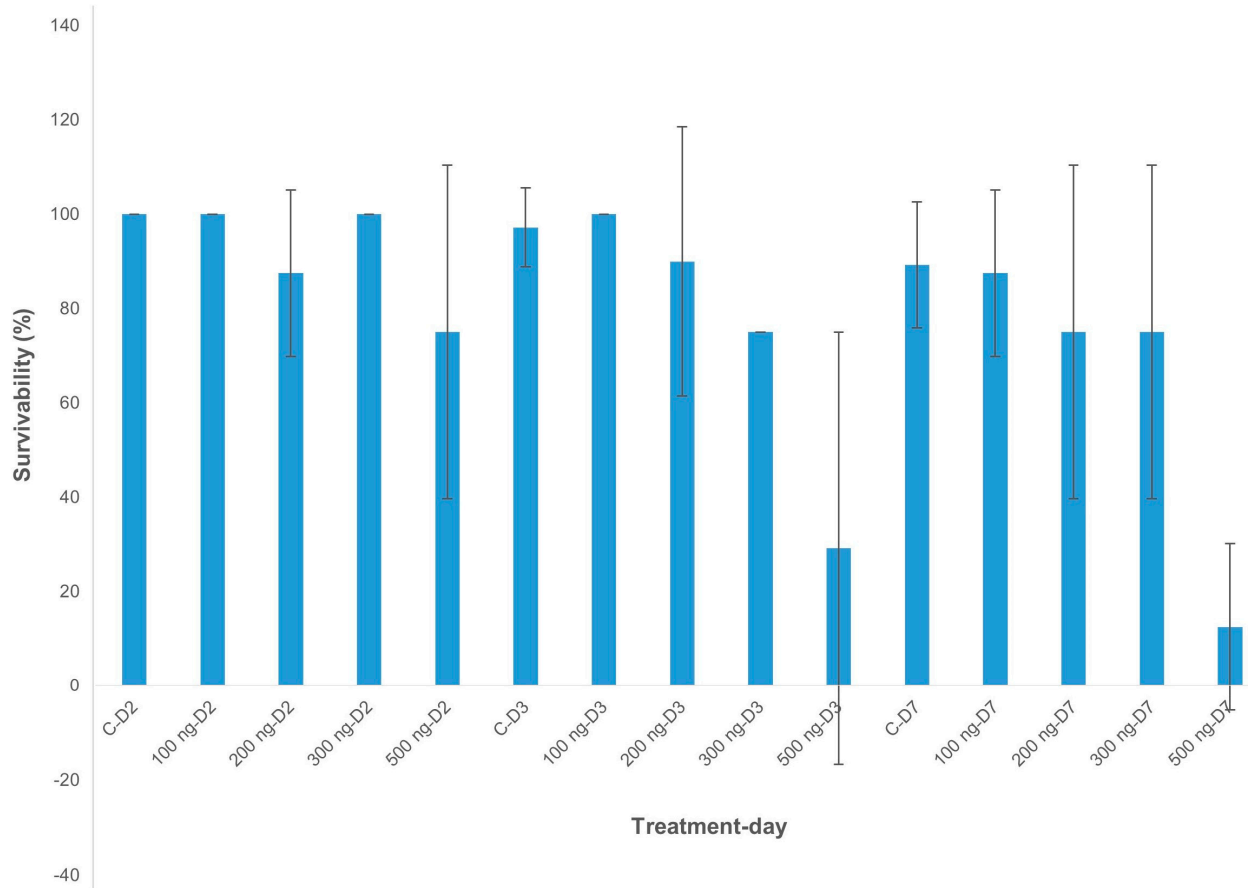

Figure 2. Banana aphid survivability curve at varying dsRNA concentrations and time intervals at day 2 (D2), day 3 (D3), and day 7 (D7). Data are presented as mean percentage survivability (\%) and error lines indicate the standard deviation.
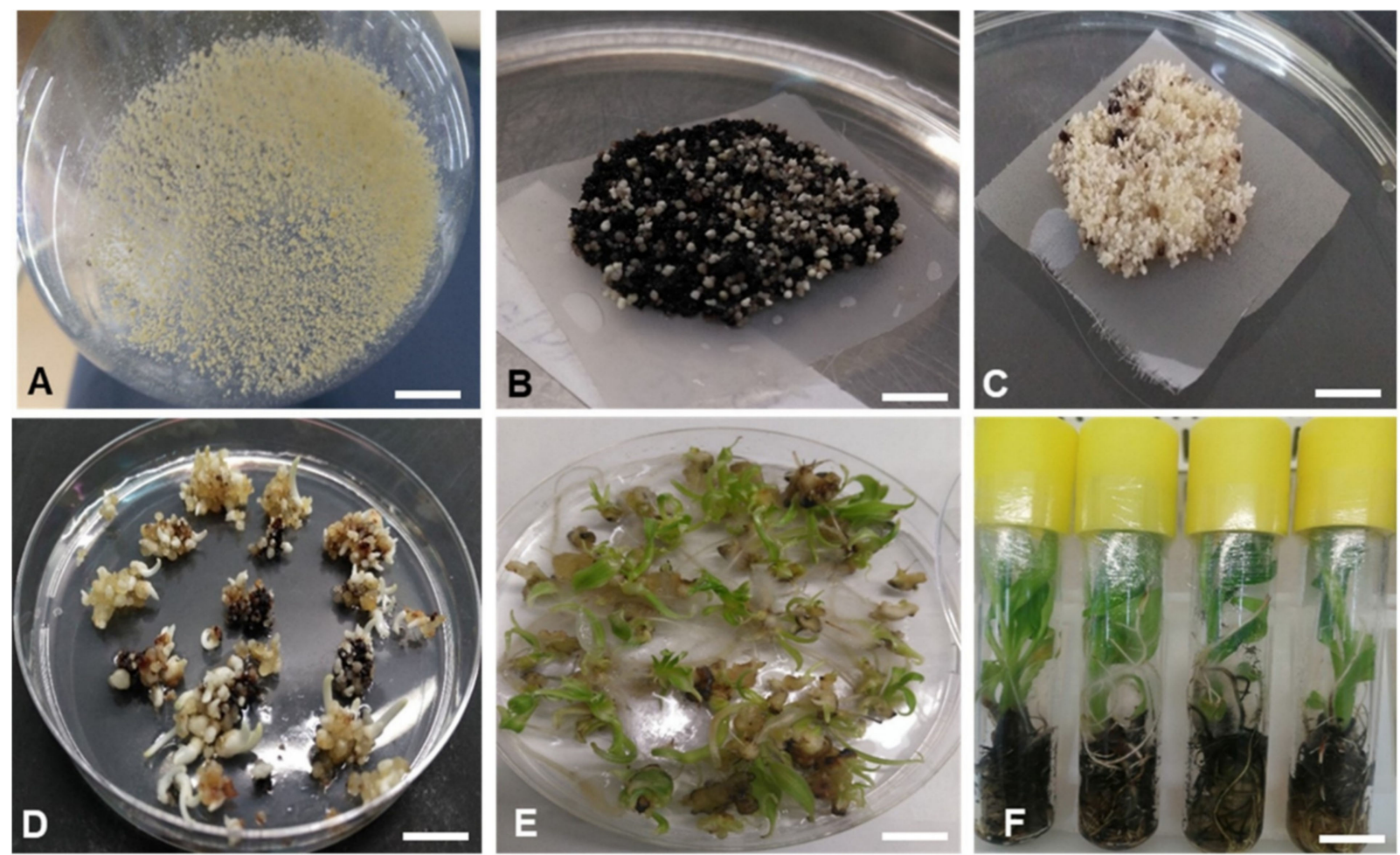

Figure 3. Transformation, selection, and regeneration of putative transgenic events. (A) Proliferating embryogenic cell suspension, (B) developing embryos on transformed embryogenic cells on selection medium, (C) developing embryos on control untransformed embryogenic cells on nonselective medium, (D,E) germinating embryos, (F) fully regenerated putative transgenic plant. Scale bar $=1 \mathrm{~cm}$. 

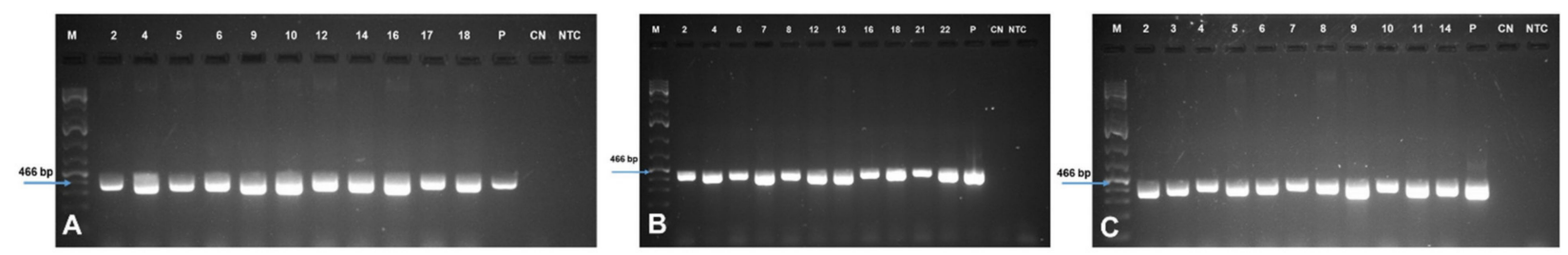

Figure 4. PCR amplification using AChE specific primers to show the presence of transgene in the transgenic banana and plantain events: (A) Cavendish Williams, (B) Orishele, (C) Gonja Manjaya. M-molecular marker 1 kb ladder; NTCnontemplate control; $\mathrm{CN}$ - control nontransgenic plant; +- plasmid as positive control, numbers on lanes of the image (A-C) indicate the independent transgenic events of Cavendish Williams, Orishele, and Gonja Manjaya, respectively.

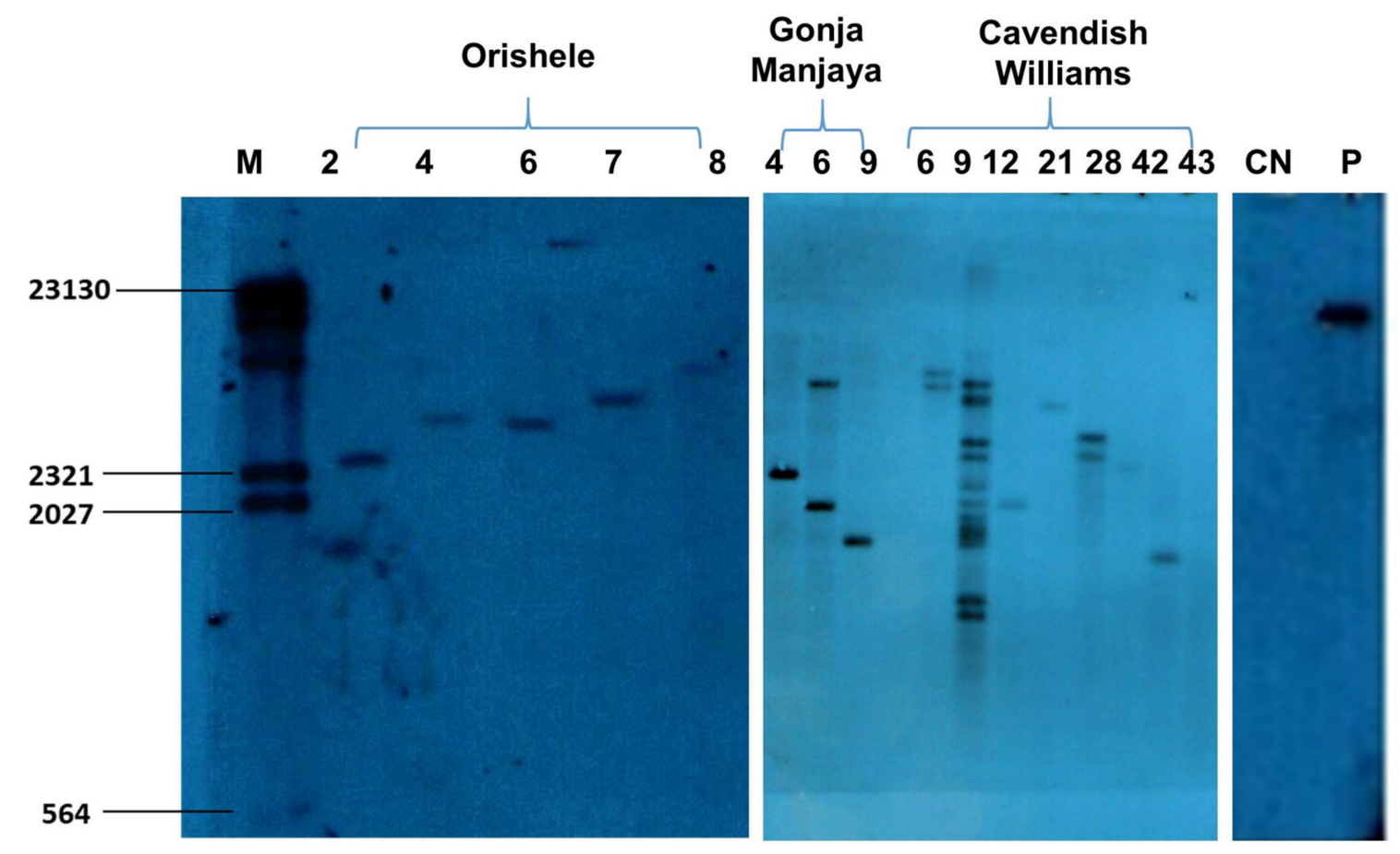

Figure 5. Southern blot analysis to confirm the integration of $A C h E$ transgene in selected transgenic events representing plantain (Orishele and Gonja Manjaya) and banana (Cavendish Williams) cultivars. $\mathrm{M}$-molecular marker; $\mathrm{CN}$ - control nontransgenic plant; $\mathrm{P}$ - plasmid DNA as positive control.

\subsection{Evaluation of Transgenic Events for Resistance to Aphids}

In total, 71 transgenic events were challenged with $P$. nigronervosa inside insect-proof cages within a conviron plant growth chamber to determine their resistance levels to the banana aphids. Five first instar aphids were placed on the pseudostem of three biological replicates of each transgenic event, and the aphid population was monitored every 7 days for 21 days. The relative decrease of banana aphid populations in comparison to the nontransgenic control was used as a measure of "relative resistance". The results showed that the transgenic banana and plantain events had varied levels of resistance to the aphids compared to control plants (Figure 7). For transgenic Cavendish Williams, four transgenic events showed an increase in the aphid population ( -0.3 to $-67.8 \%)$ relative to the control, while 28 events showed a decrease in the aphid population ranging from $7.7 \%$ to $79 \%$. In the case of Orishele, two events had a higher aphid population than the control $(-5.8 \%$ and $-10 \%$ ), while eight events showed a decrease in the aphid population (ranging from $22.6 \%$ to $75.6 \%$ ). For transgenic Gonja Manjaya, 14 out of 29 events tested, showed a decrease in aphid populations relative to the control plants, ranging between $0.7 \%$ and $46.7 \%$. However, the remaining 15 events of Gonja Manjaya showed an increase in aphid population ranging 
from $-4.8 \%$ to $-65.9 \%$ relative to the controls. A comparison between nontransgenic control plants, Agbagba, Obino 1'Ewai, Orishele, Gonja Manjaya, and Cavendish Williams, confirmed that there was no significant difference in aphid populations upon feeding across these cultivars (Figure 8).
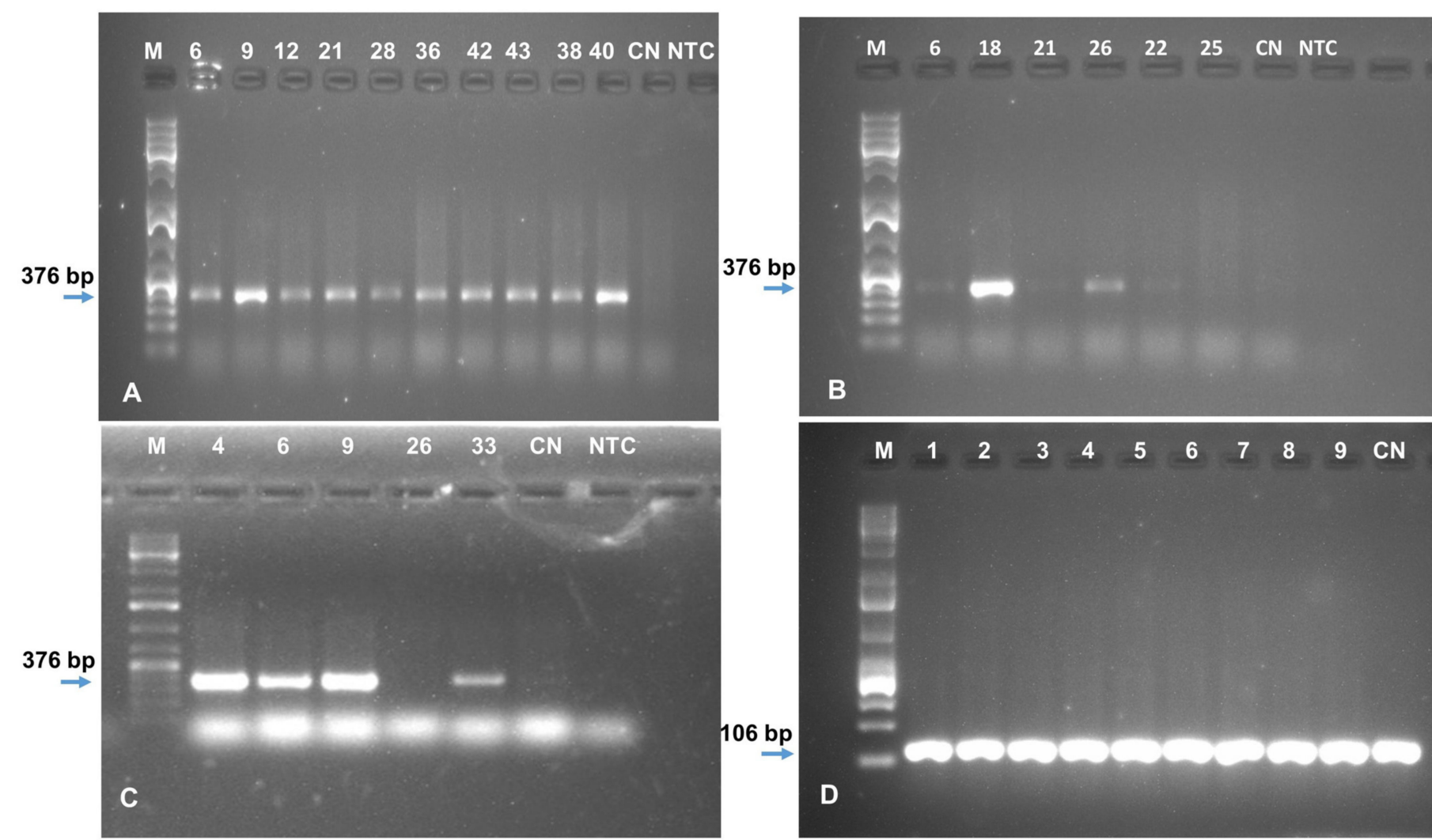

Figure 6. RT-PCR analysis to confirm expression of dsRNA- $A C h E$ in selected transgenic events. (A) Cavendish Williams, (B) Orishele, (C) Gonja Manjaya, (D) Musa 25S housekeeping gene in selected transgenic plants as an internal control. $\mathrm{M}$-molecular marker $1 \mathrm{~kb}$ ladder; CN—control nontransgenic plant; NTC—nontemplate control.

Of the cultivars tested, expression of dsRNA-AChE appeared most effective in Orishele and Cavendish Williams, with $80 \%$ and $87.5 \%$ of events showing a reduction in aphid populations compared to the controls, respectively. In contrast, only $48 \%$ of Gonja Manjaya events showed reduced aphid numbers. This is unlikely the result of cultivar preference by the aphid as there was no significant difference in mean aphid populations over time across nontransgenic plants representing these cultivars. Although there seems not to be a direct relationship between the differential expression levels and the variation in resistance in the current study, the variation in resistance levels between individual events is most likely linked to the differential expression levels of dsRNA- $A C h E$ and the stoichiometric ratio of small interfering RNAs (siRNA) accumulation, the initiators of RNAi, and the resultant sequence-specific degradation of target gene mRNA. In this study, dsRNA- $A C h E$ was nuclear-expressed and, therefore, the long $A C h E$-dsRNA is likely processed into siRNAs within the cytoplasm by Dicer before ingestion by the aphid. The siRNAs are known to be less effective at stimulating RNAi than long dsRNA templates [31]. This factor, together with other aspects such as optimal target sequence and long RNA and siRNA stability may contribute to the level of resistance and the variation in resistance observed. It was previously reported that the $\mathrm{pH}$ of an insect or midgut secretion can degrade dsRNA [32,33] and reduce the downstream systemic RNAi effect. Peng et al. [34] pointed out that depending on the insect species, the $\mathrm{pH}$ in the gut favors the activity of some nucleases, which could be more aggressive than others in degrading dsRNA. For instance, the high $\mathrm{pH}$ in the gut of some Leptidoptan species (e.g., Spodoptera litura) 
has been associated with high nucleolytic degradation of dsRNA by nucleases present there. In a study by Guo et al. [16], engineered aphid resistance was less effective when expressing hairpin RNA targeting the $M p A C h E 2$ gene compared to amiRNAs targeting two MpAChE2 sequences. Perhaps a similar amiRNA strategy would be equally effective against $P$. nigronervosa in transgenic banana and plantain. Alternatively, chloroplast-based expression of $A C h E$ dsRNA would sequester the long dsRNA from Dicer and deliver a more potent elicitor of RNAi into the aphid. Other strategies such as topical application of transdermal dsRNA delivery system using nanotechnology targeting important aphid genes have a potential of managing aphid infestation in the field [35]. However, this approach warrants investigation for its efficiency in controlling aphid population and transmission of virus during probing.

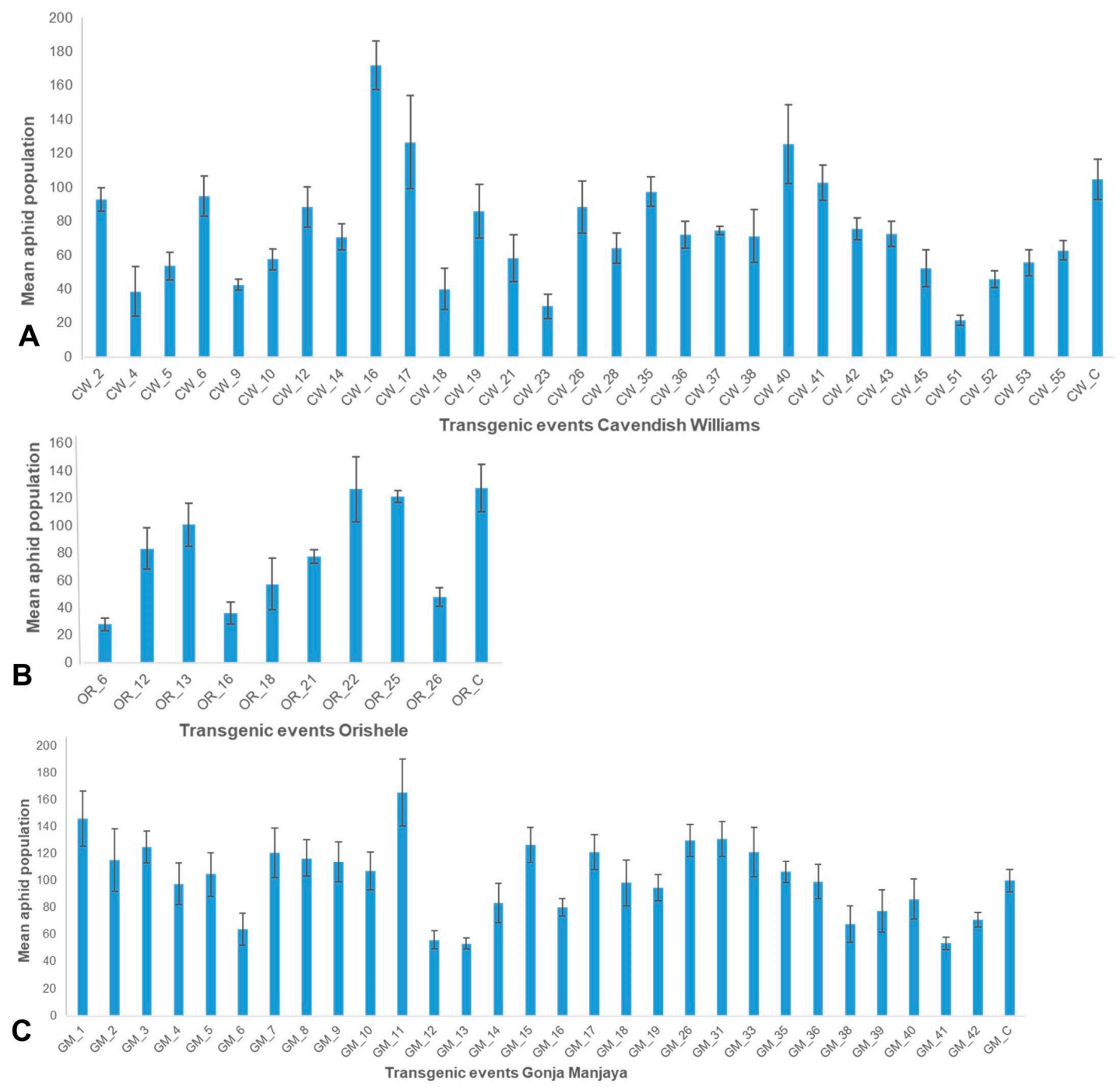

Figure 7. Relative change in aphid populations on dsRNA-AChE transgenic plants compared to nontransgenic control plants upon challenge with aphids. (A) Cavendish Williams, (B) Orishele, (C) Gonja Manjaya. The different number of transgenic events indicates the independent events generated for the three cultivars tested. Data are presented as LSmean values and standard error (SE). 


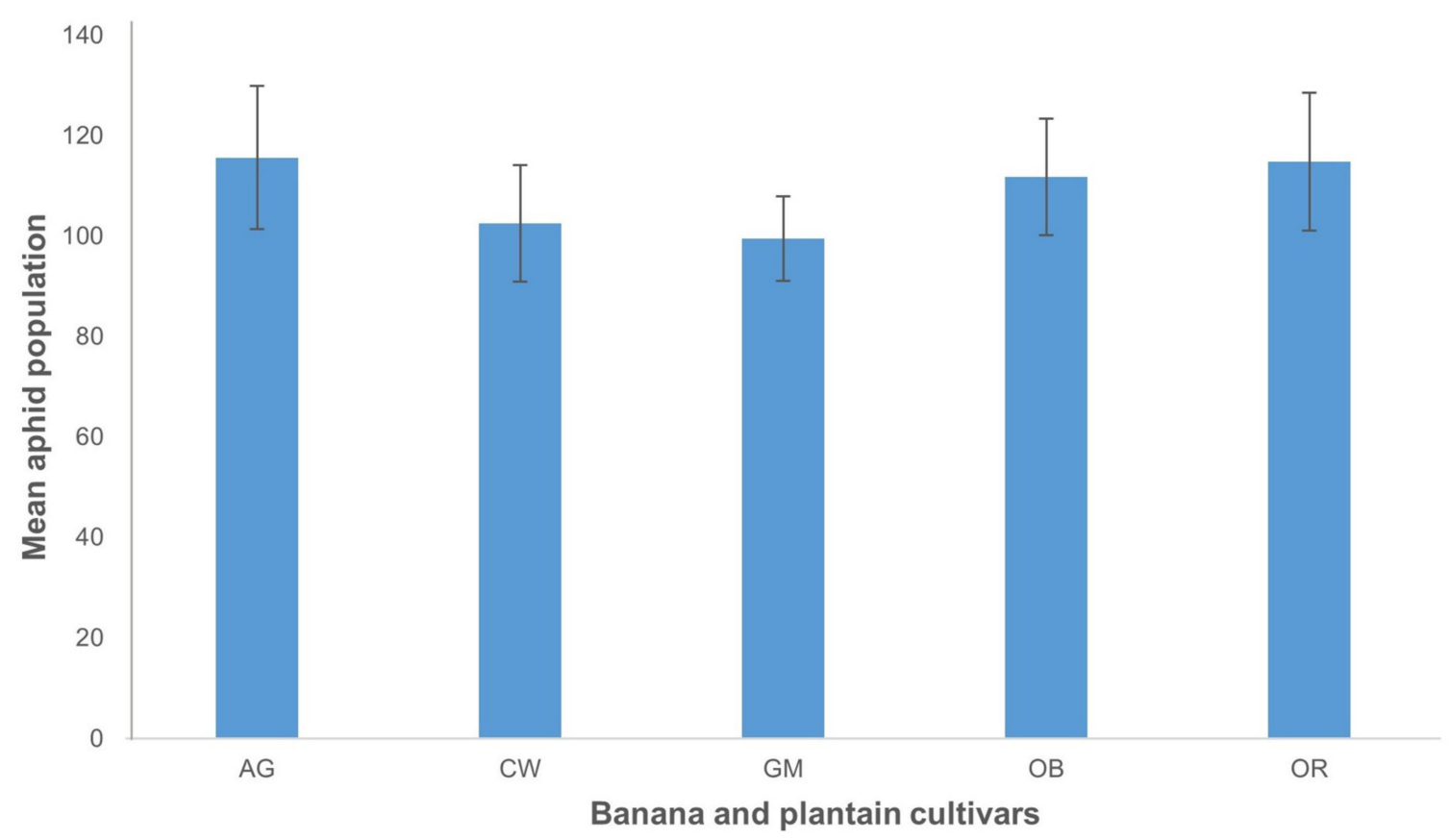

Figure 8. Mean live aphid population growing on nontransgenic plants of various cultivars of banana and plantain. AG—Agbagba, CW—Cavendish Williams, GM—Gonja Manjaya, OB-Obino l'Ewai, and OR—Orishele. Data are presented as means with standard error.

\section{Materials and Methods}

\subsection{Source of Plant Material}

One plantain cultivar Orishele, commonly grown in West Africa and preferred by farmers in that region, was obtained from the Genetic Resources Center of the International Institute of Tropical Agriculture (IITA), Nigeria. Onother plantain cultivar Gonja Manjaya, preferred by East African farmers, and one dessert banana cultivar Cavendish Williams, were obtained from the Plant Transformation Laboratory of IITA, Kenya.

\subsection{Rearing and Maintenance of Aphids in the Laboratory}

A single banana aphid (P. nigronervosa) was isolated from a banana plant in the field (GPS coordinates: latitude $-1.270224^{\circ}$, longitude $36.72312^{\circ}$, altitude $1823.00 \mathrm{~m}$ ) at the International Livestock Research Institute (ILRI) Nairobi, Kenya. The aphid was maintained on an eight-week-old potted banana plant in an insect-proof cage under natural light and temperature. After colony establishment, a single aphid was isolated from the plant and used to initiate a fresh population on a young banana plant. A pure colony was maintained by transferring the aphids to newly acclimatized potted banana plants every $4-8$ weeks.

\subsection{Optimization of an Artificial Aphid Feeding Medium}

P. nigronervosa diet compositions were prepared based on ingredients described by Douglas and van Emden [36]. The predominant modifications were in the metal complexes in place of sequestered manganese (Table 3 ) and the omission of riboflavin. In addition, increasing concentrations of sucrose $(0,5,7.5,15,20$, and 30 g per $100 \mathrm{~mL})$ were included for each diet type (Diet 1, Diet 2, Diet 3, Diet 4, and control Diet 5 containing Milli-Q water only). The $\mathrm{pH}$ of each diet was adjusted to 7.5 with $1 \mathrm{M} \mathrm{KOH}$ and filter-sterilized using a $0.2 \mu \mathrm{m}$ filter in a laminar flow hood. Diet aliquots were stored at $-20{ }^{\circ} \mathrm{C}$ and thawed immediately prior to use. 
Table 3. Diet composition for banana aphid (Pentalonia nigronervosa).

\begin{tabular}{|c|c|c|c|c|}
\hline \multirow[t]{2}{*}{ Composition } & \multicolumn{4}{|c|}{ Quantity $(\mathrm{mg}) / 100 \mathrm{~mL}$ Diet } \\
\hline & Diet 1 & Diet 2 & Diet 3 & Diet 4 \\
\hline di-potassium hydrogen orthophosphate & 750.0 & 750.0 & 750.0 & 750.0 \\
\hline magnesium sulfate & - & 123.0 & - & 123.0 \\
\hline magnesium chloride & 123.0 & - & 123.0 & - \\
\hline L-tyrosine & 40.0 & 40.0 & 40.0 & 40.0 \\
\hline L-asparagine hydrate & 550.0 & 550.0 & 550.0 & 550.0 \\
\hline L-aspartic acid & 140.0 & 140.0 & 140.0 & 140.0 \\
\hline L-tryptophan & 80.0 & 80.0 & 80.0 & 80.0 \\
\hline L-alanine & 100.0 & 100.0 & 100.0 & 100.0 \\
\hline L-arginine monohydrochloride & 270.0 & 270.0 & 270.0 & 270.0 \\
\hline L-cysteine hydrochloride, hydrate & 40.0 & 40.0 & 40.0 & 40.0 \\
\hline L-glutamic acid & 140.0 & 140.0 & 140.0 & 140.0 \\
\hline L-glutamine & 150.0 & 150.0 & 150.0 & 150.0 \\
\hline L-glycine & 80.0 & 80.0 & 80.0 & 80.0 \\
\hline L-histidine & 80.0 & 80.0 & 80.0 & 80.0 \\
\hline L-isoleucine (allo free) & 80.0 & 80.0 & 80.0 & 80.0 \\
\hline L-Leucine & 80.0 & 80.0 & 80.0 & 80.0 \\
\hline L-Lysine monohydrochloride & 120.0 & 120.0 & 120.0 & 120.0 \\
\hline L-methionine & 40.0 & 40.0 & 40.0 & 40.0 \\
\hline L-phenylalanine & 40.0 & 40.0 & 40.0 & 40.0 \\
\hline L-proline & 80.0 & 80.0 & 80.0 & 80.0 \\
\hline L-serine & 80.0 & 80.0 & 80.0 & 80.0 \\
\hline L-threonine & 140.0 & 140.0 & 140.0 & 140.0 \\
\hline L-valine & 80.0 & 80.0 & 80.0 & 80.0 \\
\hline ascorbic acid (vitamin C) & 100.0 & 100.0 & 100.0 & 100.0 \\
\hline aneurine hydrochloride (vitamin B) & 2.5 & 2.5 & 2.5 & 2.5 \\
\hline nicotinic acid & 10.0 & 10.0 & 10.0 & 10.0 \\
\hline folic acid & 0.5 & 0.5 & 0.5 & 0.5 \\
\hline (+)-pathothenic acid (calcium salt) & 5.0 & 5.0 & 5.0 & 5.0 \\
\hline myo-inositol & 50.0 & 50.0 & 50.0 & 50.0 \\
\hline choline chloride & 50.0 & 50.0 & 50.0 & 50.0 \\
\hline EDTA Fe(III)-Na chelate pure & 1.5 & - & - & - \\
\hline EDTA $\mathrm{Zn}-\mathrm{Na}_{2}$ chelate pure & 0.8 & - & - & - \\
\hline $\mathrm{MnCl}_{2} \cdot 4 \mathrm{H}_{2} \mathrm{O}$ & 0.8 & - & - & - \\
\hline EDTA $\mathrm{Cu}-\mathrm{Na}_{2}$ chelate pure & 0.4 & - & - & - \\
\hline $\mathrm{FeSO}_{4} \cdot 7 \mathrm{H}_{2} \mathrm{O}$ & - & 1.5 & - & - \\
\hline $\mathrm{ZnSO}_{4} \cdot 7 \mathrm{H}_{2} \mathrm{O}$ & - & 0.8 & - & - \\
\hline $\mathrm{MnSO}_{4} \cdot \mathrm{H}_{2} \mathrm{O}$ & - & 0.8 & - & - \\
\hline $\mathrm{CuSO}_{4} .5 \mathrm{H}_{2} \mathrm{O}$ & - & 0.4 & - & - \\
\hline pyridoxine hydrochloride (vitamin B6) & 2.5 & 2.5 & 2.5 & 2.5 \\
\hline D-biotin, crystalline & 0.1 & 0.1 & 0.1 & 0.1 \\
\hline
\end{tabular}

\subsection{Construction of Plasmids for In Vitro dsRNA Synthesis and Plant Transformation}

3.4.1. Amplification and Sequencing of a P. nigronervosa Partial AChE Gene Fragment

$A C h E$ gene sequences from related insect species were extracted from GenBank and aligned. These sequences included accessions AB158639, JQ349160, KJ755948, AY819704, KJ561353, and XM_008187580. Based on regions of homology, two primers, ACE-F1 (5'-GCTACTTAGTAGCTTCTACTTATGGACTTTC-3') and ACE-R1 (5'-CCCAAGGTGCTG TTGAGGATCCTGATTCCATGA-3') were designed to amplify approximately $1100 \mathrm{bp}$ fragment of the $A C h E$ gene from P. nigronervosa genome. Total DNA was extracted from approximately ten aphids collected from three geographical regions (including Australia, Kenya, and Cameroon) using the CTAB protocol of Stewart and Via [37]. Approximately $1 \mu \mathrm{g}$ of DNA was used as the template in a PCR containing GoTaq polymerase and primer pair ACE-F1 and ACE-R1. PCR cycles were $95^{\circ} \mathrm{C}$ for $30 \mathrm{~s}$, followed by 30 cycles of $95^{\circ} \mathrm{C}$ for $30 \mathrm{~s}, 50{ }^{\circ} \mathrm{C}$ for $30 \mathrm{~s}, 72{ }^{\circ} \mathrm{C}$ for $45 \mathrm{~s}$, and a final extension of $72{ }^{\circ} \mathrm{C}$ for $2 \mathrm{~min}$. PCR amplicons 
were gel-purified and cloned into PGEM $^{\circledR}$-T Easy (Promega) vector according to the manufacturer's guidelines. Two clones representing each geographical location were Sanger sequenced and aligned. From this, a 100\% conserved region of approximately $400 \mathrm{bp}$ mapping to exon 3 of the $A C h E$ coding region was selected for RNAi construct development.

\subsubsection{Cloning of P. nigronervosa Ache Gene Target Sequence}

Two primers, ACE400-F (5'-GATCTTAGATTTAGGCACCCTCGCCCAATTG-3') and ACE400-R (5'-AAGTCCAGCGTTCCCTGGAACATCTTC-3') were used to amplify the $400 \mathrm{bp} A C h E$ target sequence from $P$. nigronervosa total DNA. PCR was performed as described above and the amplicon similarly cloned into pGEM ${ }^{\circledR}$-T Easy vector and sequenced. The resulting plasmid named pGEMT-ACE400 was used as the template for in vitro dsRNA synthesis.

\subsubsection{Assembly of a Binary Vector Capable of Expressing P. nigronervosa AChE dsRNA}

Sense and antisense sequences of the P. nigronervosa AChE 400 bp gene target were amplified with primer pair ACE400-KpnI (5'-GTACCGATCTTAGATTTAGGCACCCTCGCCC AATTG-3') and ACE400-SacI (5'-GAGCTCAAGTCCAGCGTTCCCTGGAACATCTTC-3'), and primer pair ACE400-AsiSI (5'-GCGATCGCAAGTCCAGCGTTCCCTGGAACATCTTC$\left.3^{\prime}\right)$ and ACE400-BglII (5'-AGATCTTAGATTTAGGCACCCTCGCCCAATTG-3'), respectively. PCRs were performed as described above using pGEMT-ACE400 as the template and the amplicons cloned into $\mathrm{PGEM}{ }^{\circledR}$-T Easy vector and sequenced. The antisense and the sense fragments were excised from pGEM ${ }^{\circledR}$-T Easy vector and ligated into the AsiSI and $B g l I I$ and $K p n I$ and SacI sites respectively in the binary vector pNXT-TYMPhp to yield pNXT-35S-ACE-hp. The sense and antisense $A C h E$ fragments were separated by approximately 100 bp synthetic intron [38], to ensure stability of the hairpin. In this construct, the $A C h E$ gene is driven by the cauliflower mosaic virus (CaMV) $35 \mathrm{~S}$ promoter. The plasmid also contains $n p t I I$ gene encoding resistance to the antibiotic kanamycin for selection of transgenic plants (Figure 9). The plasmid was mobilized to Agrobacterium tumefaciens (strain EHA 105) by electroporation and used for banana transformation.

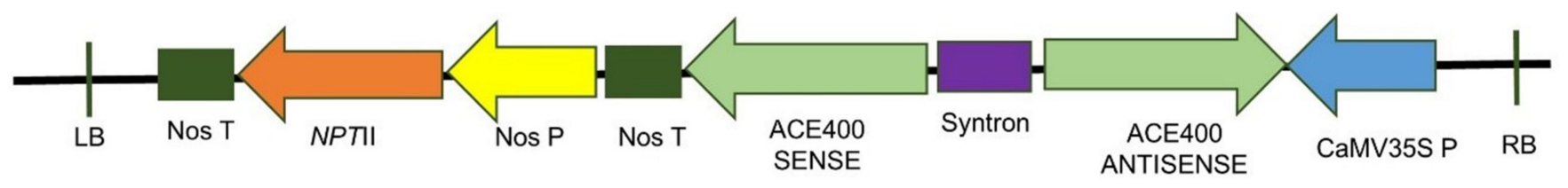

\section{pNXT-35S-ACE-hp (9576 bp)}

Figure 9. A graphical representation of the T-DNA region of the pNXT-35S-ACE hp plasmid.

\subsection{In Vitro Synthesis of dsRNA-AChE}

The pGEMT-ACE400 plasmid DNA was isolated from E. coli using an Invitrogen PureLink Quick Plasmid Miniprep Kit (K2100-10 and K2100-11). Plasmid DNA was linearized overnight at $37^{\circ} \mathrm{C}$ by restriction digestion with $\mathrm{Ncol}$ or Sall to generate templates for SP6 (sense) or T7 (antisense) in vitro transcription, respectively. Single-stranded RNA was produced using SP6 and T7 RNA polymerase (Promega, Madison, WI, USA) according to the manufacturer's specifications. Equal quantities of sense and antisense ssRNA were annealed by denaturation at $95^{\circ} \mathrm{C}$ for 2 min with a stepwise reduction of $1{ }^{\circ} \mathrm{C}$ every 2 min to an end temperature of $4{ }^{\circ} \mathrm{C}: \infty$. The final concentration of the dsRNA was determined by spectrophotometry.

\subsection{Development of an Artificial Aphid Feeding Assay and dsRNA-AChE Dose Response}

Preparation of the diet sachets and cages was done as described by Douglas and van Emden [36] using a $15 \mathrm{~mL}$ falcon tube cut into $10 \mathrm{~mm} \times 10 \mathrm{~mm}$ open ends. Rough edges 
were smoothed to avoid piercing the parafilm, which could cause diet leakage or allow the aphids to escape.

Four aphids were placed into each diet tube and sealed appropriately. Tubes were incubated in a controlled environment chamber (CMP 6050, Canada) at $25^{\circ} \mathrm{C}, 75 \% \mathrm{RH}$ and 12:12 h photoperiod and aphid numbers monitored over 5 and 7 day periods. Two independent experiments using three replicates with four aphids each per diet $(n=24)$ were performed to determine the appropriate diet for in vitro rearing of banana aphids.

For dsRNA dose-response assays, four aphids were placed in diet tubes containing Diet 2 formula (with $7.5 \% w / v$ sucrose) and increasing concentrations $(0,100,200,300$, and $500 \mathrm{ng} / \mu \mathrm{L}$ ) of in vitro synthesized $A C h E$-dsRNA. Two independent experiments using three replicate with four aphids each per diet dose $(n=24)$ were performed at 2,3 , and 7 days post-feeding.

\subsection{Agrobacterium-Mediated Transformation of Plantain and Banana and Generation of Transgenic Events}

Embryogenic cell suspension of banana cultivar, Cavendish Williams and plantain cultivars, Gonja Manjaya and Orishele were transformed using Agrobacterium tumefaceins strain EHA 105 carrying the binary vector pNXT-ACE-35S-hp and plants regenerated as described by Tripathi et al. [7]. Transgenic events were regenerated on selective media containing kanamycin $(100 \mathrm{mg} / \mathrm{L})$.

\subsection{Molecular Characterization of Transgenic Plants}

\subsubsection{Genomic DNA Extraction and Validation of Transgenic Events by PCR Analysis}

Genomic DNA was isolated from each putative transgenic event using a modified CTAB protocol as described by Tripathi et al. [7]. Presence of the transgene sequence confirmed by PCR using a forward $A C h E$ specific (F: GAGCTCAAGTCCAGCGTTCCCTGGA) and a reverse primer specific to the syntron region (R: AGAATTGGCGCGCCATTTAAATC) designed to amplify a product of $466 \mathrm{bp}$.

\subsubsection{Southern Blot Analysis to Confirm the Integration of Transgene}

About $20 \mu \mathrm{g}$ of genomic DNA was mixed with $100 \mathrm{U}$ of NcoI restriction enzyme $\mathrm{HF}$ (R3193S) and digested at $37^{\circ} \mathrm{C}$ for $18 \mathrm{~h}$. Digests (which included transgenic plants, nontransgenic control as negative control, and $A C h E$ plasmid DNA as positive control) were concentrated and electrophoresed through $0.8 \%(w / v)$ agarose gel and transferred to a positively charged nylon membrane. The membrane was hybridized with a DIGlabeled probe specific to the $A C h E-400$ fragment sequence and constituted according to manufacturer's instructions. The labeled probe and unlabeled reaction mix were incubated in a thermocycler at $95^{\circ} \mathrm{C}$ for $5 \mathrm{~min},\left(95^{\circ} \mathrm{C}\right.$ for $30 \mathrm{~s}, 60^{\circ} \mathrm{C}$ for $30 \mathrm{~s}$, and $72{ }^{\circ} \mathrm{C}$ for $1 \mathrm{~min}$ : 34 cycles), $72{ }^{\circ} \mathrm{C}$ for $2 \mathrm{~min}$ and $\left.4{ }^{\circ} \mathrm{C}: \infty\right)$. About $10 \mu \mathrm{L}$ of the labeled probe was added to $40 \mu \mathrm{L}$ of nuclease-free water, denatured in boiling water for $10 \mathrm{~min}$, and placed immediately on ice for $5 \mathrm{~min}$. The probe was hybridized to the membrane for $18 \mathrm{~h}$ at $42{ }^{\circ} \mathrm{C}$ and $60 \mathrm{rpm}$, the membrane washed, and signal detected using CDP-Star chemiluminescent substrate.

\subsubsection{RT-PCR Analysis to Confirm Expression of AChE-dsRNA in Transgenic Plants}

RNA was extracted from plant leaves using a Qiagen RNeasy Plus Mini Kit (catalog number 74134) and cDNA synthesized using a Maxima reverse transcriptase enzyme mix (Thermo Scientific, K1642 and R1362). RT-PCRs were performed using the following primer pairs: AChE specific primers (F: CCCTGGAACATCTTCAGTG; R: TAGGCACCCTCGCCCAATTG; product size: $376 \mathrm{bp}$ ) and Musa 25S housekeeping gene-specific primers (F: ACATTGTCAGGTGGGGAGTT; R: CCTTTTGTTCCACACGAGATT; product size: 106 bp). The reaction mix was incubated at $95^{\circ} \mathrm{C}$ for $15 \mathrm{~min},\left(94{ }^{\circ} \mathrm{C}\right.$ for $30 \mathrm{~s}, 57^{\circ} \mathrm{C}$ for $30 \mathrm{~s}, 72{ }^{\circ} \mathrm{C}$ for 30: 35 cycles), $72{ }^{\circ} \mathrm{C}$ for $5 \mathrm{~min}$ and storage $4{ }^{\circ} \mathrm{C}$. 


\subsubsection{Evaluation of Transgenic Events for Resistance to Aphids}

Three biological replicates of each transgenic event and nontransgenic control plants were potted into a mixture of sterile soil and chicken manure in the ratio of 3:1 and acclimatized in a greenhouse. Plants were irrigated with water and placed in a humidity chamber at $16 / 8 \mathrm{~h}$ photoperiod, $25^{\circ} \mathrm{C} \pm 2.0$ and watered sparingly every week for about 8 weeks.

Plants were placed inside an insect-proof cage and five first instar aphids inoculated onto the pseudostem of each plant. The cage was then placed inside a controlled Conviron growth chamber at $25{ }^{\circ} \mathrm{C}, 75 \%$ relative humidity with a $12 \mathrm{~h}$ photoperiod (Figure 10). The population of aphids was counted every 7 days after inoculation for 21 days. This experiment was repeated three times for statistical relevance.
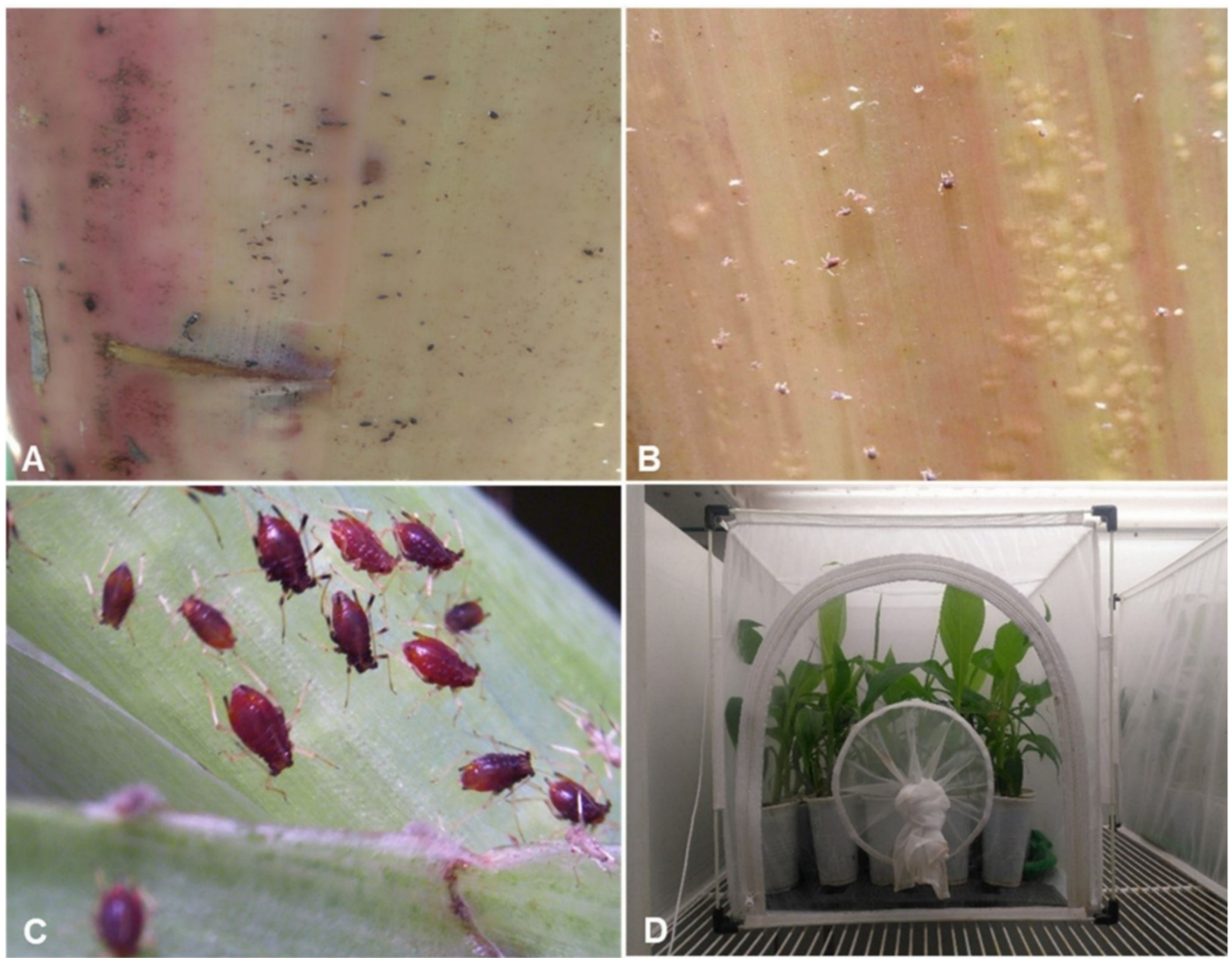

Figure 10. Evaluation of transgenic banana and plantains expressing $A C h E$-dsRNA by challenging with aphids. (A-C) Aphids rearing on the leaves of a nontransgenic banana plant and (D) aphid-challenged transgenic plants in an insect-proof cage within a controlled environment chamber.

\subsection{Statistical Analysis}

The statistical analysis was done using the generalized linear model (PROC GLM) using the Statistical Analysis System (SAS V 9.4, Cary, NC, USA) to do the analysis of variance (ANOVA) so as to obtain the variance components and least square means (LSMEANS). The Dunnett's test was to compare the treatments to their respective controls. The percentage relative resistance was estimated based on aphid numbers on transgenic events compared to aphid numbers on control plants using the formula

$$
X(\%)=[(a-b) \div a] \times 100
$$

where $\mathrm{X}$ is relative resistance or percentage decrease, a is average aphid population on control plants, and $\mathrm{b}$ is average aphid population on transgenic plant. 


\section{Conclusions}

RNAi is a convenient means of engineering resistance to plant pests and diseases. Pentalonia nigronervosa is a sap-sucking aphid and the sole insect vector of BBTV, the causal agent of the destructive bunchy top disease affecting bananas and plantains. In this study, we targeted the $A C h E$ gene of $P$. nigronervosa using dsRNA to elicit an RNAi response with a lethal effect to the insect. The delivery of $A C h E$ long dsRNA in vitro within an artificial aphid feeding medium was detrimental to aphid growth and reproduction, with a dose of $500 \mathrm{ng} / \mu \mathrm{L}$ being most lethal. Banana and plantains engineered to express the same $A C h E$-dsRNA showed varying levels of resistance to the aphid as determined by a reduction in aphid populations compared to control nontransgenic plants. The best of these events showed a $67.8 \%$ (cv. Cavendish Williams) and 75.6\% (cv. Orishele) reduction in aphid populations over a period of 21 days. To the best of our knowledge, this is the first report of transgenic banana and plantain with enhanced resistance to P. nigronervosa. These elite transgenic events represent a significant step forward in the fight against BBTV; however, only with long-term field assessment can their resistance to both aphid and virus be thoroughly evaluated.

Author Contributions: Conceptualization, L.T.; methodology, T.J., J.N.T., L.T., and B.D.; validation, T.J., L.T., J.N.T., G.O., E.M., and B.D.; formal analysis, T.J.; investigation, T.J.; resources, L.T. and J.D.; data curation, T.J.; writing—original draft preparation, T.J.; writing—review and editing, T.J., L.T., J.N.T., E.M., G.O., B.D., and J.D.; visualization, T.J.; supervision, L.T., J.N.T., E.M., G.O., B.D., and J.D.; project administration, L.T.; funding acquisition, L.T. and J.D. All authors have read and agreed to the published version of the manuscript.

Funding: This research was funded by Bill and Melinda Gates Foundation (BMGF), grant number OPP1087428.

Institutional Review Board Statement: Not applicable.

Informed Consent Statement: Not applicable.

Data Availability Statement: The data presented in this study are available on request from the corresponding author.

Acknowledgments: Authors would like to thank the Bill and Melinda Gates Foundation for funding the research. We would also like to thank Benard Mware, Valentine Otang Ntui, and Nicholas Ndiwa for their technical assistance.

Conflicts of Interest: The authors declare no conflict of interest.

\section{References}

1. Lowe, S.; Browne, M.; Boudjelas, S.; De Poorter, M. 100 of the World's Worst Invasive Alien Species; Invasive Species Specialist Group (ISSG): Auckland, New Zealand, 2000.

2. Dale, J.L. Banana bunchy top: An economically important tropical plant virus disease. Adv. Virus Res. 1987, 33, 301-325. [CrossRef]

3. Jekayinoluwa, T.; Tripathi, L.; Tripathi, J.N.; Ntui, V.O.; Obiero, G.; Muge, E.; Dale, J. RNAi Technology for Management of Banana Bunchy Top Disease (BBTD). Food Energy Secur. 2020. [CrossRef] [PubMed]

4. Selvarajan, R.; Balasubramanian, V. Host-virus interactions in banana-infecting viruses. In Plant Virus-Ost Interaction: Molecular Approaches and Viral Evolution; Gaur, R., Hohn, T., Sharma, P., Eds.; Elsevier: Amsterdam, The Netherlands, 2014; pp. 57-72.

5. Jekayinoluwa, T.; Tripathi, J.N.; Obiero, G.; Muge, E.; Dale, J.; Tripathi, L. Developing Plantain for Resistance to Banana Aphids by RNA Interference. Proceedings 2020, 36, 54. [CrossRef]

6. Shekhawat, U.K.S.; Ganapathi, T.R.; Hadapad, A.B. Transgenic banana plants expressing small interfering RNAs targeted against viral replication initiation gene display high-level resistance to banana bunchy top virus infection. J. Gen. Virol. 2012, 93, 1804-1813. [CrossRef] [PubMed]

7. Tripathi, J.N.; Ntui, V.O.; Ron, M.; Muiruri, S.K.; Britt, A.; Tripathi, L. CRISPR/Cas9 editing of endogenous banana streak virus in the B genome of Musaspp. overcomes a major challenge in banana breeding. Commun. Biol. 2019, 2, 1-11. [CrossRef] [PubMed]

8. Dale, J.; James, A.; Paul, J.-Y.; Khanna, H.; Smith, M.; Peraza-Echeverria, S.; Garcia-Bastidas, F.; Kema, G.; Waterhouse, P.; Mengersen, K.; et al. Transgenic Cavendish bananas with resistance to Fusarium wilt tropical race 4. Nat. Commum. 2017, 8, 1496. [CrossRef] 
9. Paul, J.-Y.; Khanna, H.; Kleidon, J.; Hoang, P.; Geijskes, J.; Daniells, J.; Zaplin, E.; Rosenberg, Y.; James, A.; Mlalazi, B.; et al. Golden bananas in the field: Elevated fruit pro-vitamin A from expresion of a single banana transgene. Plant Biotechnol. J. 2017, 15, 520-532. [CrossRef]

10. Baum, J.A.; Bogaert, T.; Clinton, W.; Heck, G.R.; Feldmann, P.; Ilagan, O.; Johnson, S.; Plaetinck, G.; Munyikwa, T.; Pleau, M.; et al. Control of coleopteran insect pests through RNA interference. Nat. Biotechnol. 2007, 25, 1322-1326. [CrossRef]

11. Zha, W.; Peng, X.; Chen, R.; Du, B.; Zhu, L.; He, G. Knockdown of midgut genes by dsRNA-transgenic plant-mediated RNA interference in the Hemipteran insect Nilaparvata lugens. PLoS ONE 2011, 6, e20504. [CrossRef]

12. Laudani, F.; Strano, C.P.; Edwards, M.G.; Malacrinò, A.; Campolo, O.; Abd El Halim, H.M.; Gatehouse, A.M.R.; Palmeri, V. RNAi-mediated gene silencing in Rhynchophorus ferrugineus (Oliver) (Coleoptera: Curculionidae). Open Life Sci. 2017, 12, 214-222. [CrossRef]

13. Poreddy, S.; Li, J.; Baldwin, I.T. Plant-mediated RNAi silences midgut-expressed genes in congeneric lepidopteran insects in nature. Bmc Plant Biol. 2017, 17, 1-10. [CrossRef]

14. Knorr, E.; Fishilevich, E.; Tenbusch, L.; Frey, M.L.F.; Rangasamy, M.; Billion, A.; Worden, S.E.; Gandra, P.; Arora, K.; Lo, W.; et al. Gene silencing in Tribolium castaneum as a tool for the targeted identification of candidate RNAi targets in crop pests. Sci. Rep. 2018, 8, 1-15. [CrossRef]

15. Yoon, J.S.; Mogilicherla, K.; Gurusamy, D.; Chen, X.; Chereddy, S.C.R.R.; Palli, S.R. Double-stranded RNA binding protein, Staufen, is required for the initiation of RNAi in coleopteran insects. Proc. Natl. Acad. Sci. 2018, 115, 8334-8339. [CrossRef]

16. Guo, H.; Song, X.; Wang, G.; Yang, K.; Wang, Y.; Niu, L.; Chen, X.; Fang, R. Plant-generated artificial small RNAs mediated aphid resistance. PLoS ONE 2014, 9, e97410. [CrossRef] [PubMed]

17. Whyard, S.; Singh, A.D.; Wong, S. Ingested double-stranded RNAs can act as species-specific insecticides. Insect Biochem. Mol. Biol. 2009, 39, 824-832. [CrossRef]

18. Soreq, H.; Seidman, S. Acetylcholinesterase-new roles for an old actor. Perspective. Nat. Rev. 2001, 2, 294. [CrossRef] [PubMed]

19. Fremaux, I.; Mazeres, S.; Brisson-Lougarre, A.; Arnaud, M.; Ladurantie, C.; Fournier, D. Improvement of Drosophila acetylcholinesterase stability by elimination of a free cysteine. BMC Biochem. 2002. Available online: http://www.biomedcentral.com/ 1471-2091/3/21 (accessed on 8 January 2021).

20. Pang, Y.P.; Singh, S.K.; Gao, Y.; Lassiter, T.L.; Mishra, R.K.; Zhu, K.Y.; Brimijoin, S. Selective and Irreversible Inhibitors of Aphid Acetylcholinesterases: Steps Toward Human-Safe Insecticides. PLoS ONE 2009, 4, e4349. [CrossRef]

21. Dou, D.; Park, J.G.; Rana, S.; Madden, B.J.; Jiang, H.; Pang, Y.-P. Novel selective and irreversible mosquito aetylcholinesterase inhibitors for controlling malaria and other mosquito-borne diseases. Sci. Rep. 2013, 3, 1068. [CrossRef]

22. Sabri, A.; Vandermoten, S.; Leroy, P.D.; Haubruge, E.; Hance, T.; Thonart, P.; Francis, F. Proteomic Investigation of Aphid Honeydew Reveals an Unexpected Diversity of Proteins. PLoS ONE 2013, 8, e74656. [CrossRef]

23. Akey, D.H.; Beck, S.D. Nutrition of the pea aphid, Acyrthosiphon pisum: Requirements for trace metals, sulphur, and cholesterol. J. Insect Physiol. 1972, 18, 1901-1914. [CrossRef]

24. Dadd, R.H.; Mittler, T.E. Permanent culture of an aphid on a totally synthetic diet. Experientia 1966, 22, 832-833. [CrossRef]

25. Srivastava, P.N.; Auclair, J.L. Influence of Sucrose Concentration on Diet Uptake and Performance by the Pea Aphid, Acyrthosiphon pisum. Ann. Entomol. Soc. Am. 1971, 64, 739-743. [CrossRef]

26. Dvir, H.; Silman, I.; Harel, M.; Rosenberry, T.L.; Sussman, J.L. Acetylcholinesterase: From 3D structure to function. Chem. Biol. Interact. 2010, 187, 10-22. [CrossRef]

27. Colovic, M.B.; Krstic, D.Z.; Lazarevic-Pasti, T.D.; Bondzic, A.M.; Vasic, V.M. Acetylcholinesterase Inhibitors: Pharmacology and Toxicology. Curr. Neuropharmaccol. 2013, 11, 315-335. [CrossRef]

28. Kishk, A.; Hijaz, F.; Anber, H.A.I.; AbdEl-Raof, T.K.; El-Sherbeni, A.E.H.D.; Hamed, S.; Killiny, N. RNA interference of acetylcholinesterase in the Asian citrus psyllid, Diaphorina citri, increases its susceptibility to carbamate and organophosphate insecticides. Pestic. Biochem. Physiol. 2017, 143, 81-89. [CrossRef]

29. Wuriyanghan, H.; Rosa, C.; Falk, B.W. Oral delivery of double-stranded RNAs and siRNAs induces RNAi effects in the potato/tomato psyllid, Bactericerca cockerelli. PLoS ONE 2011, 6, e27736. [CrossRef]

30. Majidiani, S.; PourAbad, R.F.; Laudani, F.; Campolo, O.; Zappala, L.; Rahmani, S.; Mohammadi, S.A.; Palmeri, V. RNAi in Tuta absoluta management: Effects of injection and root delivery of dsRNAs. J. Pest Sci. 2019, 92, 1409-1419. [CrossRef]

31. Zhang, J.; Khan, S.A.; Hasse, C.; Ruf, S.; Heckel, D.G.; Bock, R. Full crop protection from an insect pest by expression of long double-stranded RNAs in plastids. Science 2015, 347, 991-994. [CrossRef]

32. Christiaens, O.; Smagghe, G. The challenge of RNAi-mediated control of hemipterans. Insect Sci. 2014, 6, 15-21. [CrossRef]

33. Ghodke, A.B.; Good, R.T.; Golz, J.F.; Russell, D.A.; Edwards, O.; Robin, C. Exracellular endonucleases in the midgut of Myzus persicae may limit the efficacy of orally delivered RNAi. Sci. Rep. 2019. [CrossRef]

34. Peng, Y.; Wang, K.; Fu, W.; Sheng, C.; Han, Z. Biochemial comparison of dsRNA degradation nucleases in four different insects. Front. Physiol. 2018, 9, 624. [CrossRef] [PubMed]

35. Yan, S.; Qian, J.; Cai, C.; Ma, Z.; Li, J.; Yin, M.; Ren, B.; Shen, J. Spary method application of transdermal dsRNA delivery system for efficient gene silencing and pest control on soybean aphid Aphis Glycines. J. Pest Sci. 2020, 93, 449-459. [CrossRef]

36. Douglas, A.E.; van Emden, H.F. Nutrition and Symbiosis. In Aphid as Crop Pests, CABI, 2nd ed.; Van Emden, H.F., Harrington, R., Eds.; CABI: Wallingford, UK, 2007; pp. 115-130. [CrossRef] 
37. Stewart, C.N.; Via, L.E. A rapid CTAB DNA isolation technique useful for RAPD fingerprinting and other PCR applications. Biotechniques 1993, 14, 751-752, 754.

38. Dugdale, B.; Mortimer, C.L.; Kato, M.; James, T.A.; Harding, R.M.; Dale, J.L. In plant activation: An inducible, hyperexpression platform for recombinant protein production in plants. Plant Cell 2013, 25, 2429-2443. [CrossRef] [PubMed] 